\title{
Large Cell Carcinoma
}

National Cancer Institute

\section{Source}

National Cancer Institute. Large Cell Carcinoma. NCI Thesaurus. Code C3780.

A malignant epithelial neoplasm composed of large, atypical cells. 